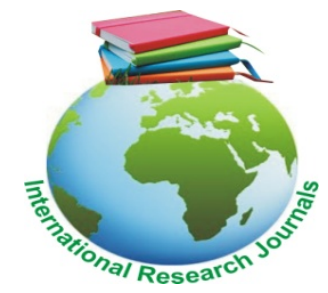

African Journal of Food Science and Technology (ISSN: 2141-5455) Vol. 6(6) pp. 177-184, September, 2015 Available online @http://www.interesjournals.org/AJFST

Full Length Research Paper

\title{
The feed value of composite mango (Mangiferaindica) fruit reject meal in the finisher broiler chickens nutrition
}

\author{
Kanan Tyohemba Orayaga ${ }^{1}$, Oluwabiyilkeolu Atanda Oluremi ${ }^{1}$,Comfort Dooshima Tuleun ${ }^{1}$ and \\ Silvanus Ngbede Carew $^{2}$
}

${ }^{1}$ Department of Animal Nutrition ${ }^{2}$ Department of Animal Production University of Agriculture, PMB 2373, Makurdi, Benue State, Nigeria.

Corresponding Author Email: orayacollins@yahoo.com Tel.+234-(0)8150943122

\begin{abstract}
Investigation was made on the nutrient composition of composite mango fruit reject meal (MFRM) and its effect on the performance of finisher broiler chickens. MFRM was analyzed for chemical compositionand incorporated into broiler dietsat $0,5,10,15$ and $20 \%$ to obtain five diets. Two hundred 28day-old Marshall broiler chicks were randomly allocated to five treatments in a completely randomised design and fed for $\mathbf{4 2}$ days. Proximate composition showed that MFRM has a low protein

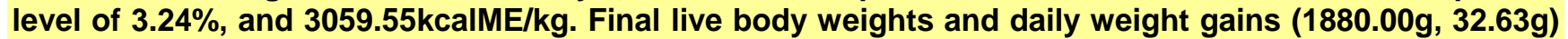
were significantly depressed $(P<0.05)$ from $15 \%$ level of MFRM inclusion. There was no significant difference $(P>0.05)$ for feed intake among the treatment groups. Feed conversion ratio was significantly depressed $(P<0.05)$ at20\% MFRM. Protein conversion efficiency was significantly different $(P<0.05)$, decreasing as the level of MFRM increased. The cost $/ \mathrm{kg}$ weight gain was not significantly affected $(P>0.05)$. Mango fruit reject meal supported growth performance of finisher broiler at $10 \%$ level, and can be a feed resource in finisher broiler diets. It is recommended that the optimum level of MFRM inclusion be investigated between $10 \%$ and $15 \%$ levels of MFRM inclusion.
\end{abstract}

Key words: mango, fruit, reject, proximate, finisher broiler chicken

\section{INTRODUCTION}

Many more non-conventional feed resources are yet to be incorporated into the feed bank for low cost animal production. This is because some of them could be gotten free or at very low costs(Orayaga and Anugwa, 2014). Agro-industrial by-products such as maize cobs (Oyadesi et al., 2012), citrus fruit peels ( Orayaga et al., 2012), mango fruit peels (Roa et al., 2003), mango fruit pulp (Soomro et al., 2013) and mango seed kernel (Oluremi and Musa, 2004; Diarra and Usman, 2008) have been identified as feed resources. Mango (Mangiferaindica) fruit is one of the most popular, nutritionally rich fruits with unique flavor, fragrance, taste, and health promoting qualities. These qualities make it a common ingredient in new functional foods. The tree is believed to have originated from the Sub-Himalayan plains of Indian sub-continent. Botanically, mango belongs within the family of Anacardiaceae (Berardini et al., 2005). It is produced on a large scale around many countries of the world, with total world figure put at 38 million metric tones (USDA, 2010). According to Wikipedia (2010), Nigeria occupied the $8^{\text {th }}$ position on the list of top-most producers of mango around the world as at 2006.

However, the fruit could be considered unfit for human consumption due to bruises, infections, improper handling, and activities of animals (especially birds) on the fruit, and as such rejected (Valdez et al., 2012). These rejected fruits, also known as cull fruits (Sruamsiri 
Table 1. Composition (\%) Of Experimental Diets for Finisher Broiler Chickens

\begin{tabular}{llllll}
\hline & \multicolumn{5}{c}{ Experimental diets } \\
\cline { 2 - 6 } Ingredients & 54.86 & 49.86 & 44.86 & 39.86 & 34.86 \\
Maize & 24.69 & 24.69 & 24.69 & 24.69 & 24.69 \\
Soybean meal & 9.00 & 9.00 & 9.00 & 9.00 & 9.00 \\
Maize offal & 5.00 & 5.00 & 5.00 & 5.00 & 5.00 \\
Brewers dried grain & 0 & 5.00 & 10.00 & 15.00 & 20.00 \\
MFRM & 2.50 & 2.50 & 2.50 & 2.50 & 2.50 \\
Bone meal & 0.50 & 0.50 & 0.50 & 0.50 & 0.50 \\
Limestone & 2.50 & 2.50 & 2.50 & 2.50 & 2.50 \\
Blood meal & 2.50 & 2.50 & 2.50 & 2.50 & 2.50 \\
Methionine & 0.20 & 0.20 & 0.20 & 0.20 & 0.20 \\
Lysine & 0.25 & 0.25 & 0.25 & 0.25 & 0.25 \\
Common Salt & 0.25 & 0.25 & 0.25 & 0.25 & 0.25 \\
Premix* & 100.00 & 100.00 & 100.00 & 100.00 & 100.00 \\
\hline Total & & & & &
\end{tabular}

and Silman, 2009) litter the ground during its season, constituting environmental hazard. Emphasis on the processing of mango fruit has been to generate products for human consumption.Even value addition to the rejected fruit has been done with more attention given to generation of products for human consumption (Valdez et al., 2012). However, the seed and peel of mango fruits have been utilized in animal feeding. According to Roaet al. (2003), dried mango peels included in finishing pig diets at $10 \%$ had no deleterious effect on feed conversion ratio, animal performance and was cost effective. The kernels are not well utilized by pigs because of high tannin content (Gohl, 1982). Inclusion rate as low as 5 to $10 \%$ of mango seed kernel depressed growth and feed intake in broilers (Diarra and Usman, 2008). Odunsi (2005) reported that growth performance was maintained at $10 \%$ inclusion of mango seed kernel meal in laying type birds' diet but egg laying was depressed even at $5 \%$ level of inclusion. Residue from mango juice factory (a mixture of peels, kernels and discarded fruits) has lower value in poultry than the seed kernel alone. Feeding trials on broiler chickens with diets balanced for protein and energy resulted in depressed performance at $2.5 \%$ level of inclusion of mango fruit residue (Vieira et al., 2008). Freshly harvested mango can however replace $33 \%$ of rabbit diet without adverse effect (Palma Castillo and Hurtado, 2009). Although the seed and peel of mango fruits have been utilized in animal feeding, a large quantity of the pulp and peel of rejected fruits waste away in Nigeria. However, considering the high nutrients (energy, vitamin $A$, vitamin $C$ and polyphenols) value of mango fruits (FAO, 2011), these rejected fruits could serve as a feed resource in animal feeding, mainly as a source of energy because of its high energy - $100 \mathrm{kcal} / \mathrm{oz}$ (3527.34 kcal $/ \mathrm{kg})$ DM (Porter, 2011)), and at the same time check its negative impact on the environment.

This research therefore investigated the performance of finisher broiler chickens fed diets containing graded levels of mango fruit reject meal.

\section{MATERIALS AND METHODS}

\section{Experimental site}

The experiment was conducted at the experimental Poultry house of the Livestock unit, on the Teaching and Research Farm, University of Agriculture Makurdi, Benue State, Nigeria. The area is warm with a minimum temperature range of $21.71 \pm 3.43^{\circ} \mathrm{C}$ and a maximum temperature range of $32.98 \pm 2.43^{\circ} \mathrm{C}(\mathrm{TAC}, 2011)$.

\section{Preparation of Mango fruit reject meal and diets}

The mango fruit rejects(test ingredient) were collected without reference to variety from mango tree stands and fruit markets around Makurdi town and environs in its season-between March and May. The composite comprising Julie, Peter, Alphonso, Hindi, John and local mango varieties was cleaned, sliced (peel and pulp together), sun dried for seven days until it attained about $10 \%$ moisture, and stored in polyethylene sacks until it was used. Before the composite mango fruit reject was incorporated into the diets, it was milled using corn milling machine to obtain mango fruit reject meal (MFRM) shown in.

Mango fruit reject meal was then incorporated in broiler diets at $0,5,10,15$ and $20 \%$ to give diets T1, T2, T3, T4 and T5 for finisher broiler chicken (Table 1).Nutrients levels in the diets were evaluated by calculation (Table 2)and by laboratory analysis (Table 3 ) were obtained.

MFRM= Mango fruit reject meal, NFE= Nitrogen free extract

Premix ${ }^{*}=$ Animal care vitamin/mineral premix included at $0.25 \%$, translating to 24000 iu vitamin $\mathrm{A}, 6000 \mathrm{iu}$ vitamin $\mathrm{B}, 60 \mathrm{mg}$ vitamin $\mathrm{E}, 5 \mathrm{mg}$ vitamin $\mathrm{K} 3,2 \mathrm{mg}$ Folic acid, $80 \mathrm{mg}$ Niacin, $20 \mathrm{mg}$ calpan, $4 \mathrm{mg}$ vitamin B1, $10 \mathrm{mg}$ 
Table 2. Calculated Values of Nutrients in Experimental Diets

\begin{tabular}{llllll}
\multicolumn{7}{c}{ Experimental diets } \\
\hline Nutrient & T1 & T2 & T3 & T4 & T5 \\
\hline M.E (kcal/kg) & 3107.92 & 3087.92 & 3067.92 & 3047.92 & 3027.92 \\
Crude protein (\%) & 20.41 & 20.12 & 19.83 & 19.55 & 19.26 \\
Crude fibre (\%) & 4.95 & 4.98 & 4.99 & 5.00 & 5.12 \\
Crude fat & 4.12 & 4.00 & 3.98 & 3.96 & 3.94 \\
Calcium (\%) & 1.30 & 1.30 & 1.30 & 1.30 & 1.30 \\
Phosporus (\%) & 0.85 & 0.85 & 0.86 & 0.86 & 0.86 \\
Lysine (\%) & 1.10 & 1.08 & 1.08 & 1.06 & 1.06 \\
Methionine (\%) & 0.58 & 0.58 & 0.57 & 0.57 & 0.56 \\
\hline
\end{tabular}

Table 3. Laboratory AnalysedNutrients Levels of Experimental Diets

\begin{tabular}{llllll}
\multicolumn{7}{c}{ Experimental diets } \\
\hline Nutrient & T1 & T2 & T3 & T4 & T5 \\
\hline Gross Energy kcal/kg & 3127.71 & 3039.70 & 2908.74 & 3049.78 & 2958.17 \\
ME** kcal/kg $^{*}{ }^{*}$ (3154.00 & 3095.91 & 2937.15 & 3076.71 & 2983.80 \\
Crude Protein (\%) & 21.63 & 24.69 & 20.40 & 19.65 & 21.80 \\
Crude fibre (\%) & 5.16 & 5.16 & 5.78 & 5.90 & 5.73 \\
Crude fat (\%) & 5.36 & 4.68 & 2.02 & 5.35 & 4.37 \\
NFE\% & 53.97 & 49.81 & 56.82 & 53.86 & 51.26 \\
Ash (\%) & 4.88 & 5.28 & 5.25 & 5.09 & 5.12 \\
& & & & & \\
\hline
\end{tabular}

Vitamin B2, 7mg vitamin B6, 0.04mg Vitamin B12, $0.16 \mathrm{mg}$ Biotin and $250 \mathrm{mg}$ antioxidant per $\mathrm{kg}$ diet. The minerals values per $\mathrm{kg}$ diet were: cobalt $0.5 \mathrm{mg}$, copper $16 \mathrm{mg}$, selenium $0.5 \mathrm{mg}$, iodine $24 \mathrm{mg}$, iron $80 \mathrm{mg}$, manganese $140 \mathrm{mg}$, zinc $120 \mathrm{mg}$ and chloride $400 \mathrm{mg}$ $\mathrm{ME}^{* *}=$ metabolizable energy calculated from the determined proximate components using the formula $\mathrm{ME}=37(\% \mathrm{CP})+81.8(\% \mathrm{EE})+35.5(\% \mathrm{NFE})$ by Pauzenga (1985)

\section{Experimental birds, design and duration}

Two hundred 28-day old Marshall Broiler chickens were used in the experiment which lasted for six weeks (42 days) in a completely randomized design.Broiler chickens were randomly allocated to 5 dietary treatments, replicated four times and each replicate had ten (10) birds. Allocation of replicates to pens was also randomized.

\section{Management of experimental birds}

The 28-day old Broiler chickens were raised in a deep litter half -walled house, having its upper half covered with wire mesh. Feed and clean cool water were supplied to the birds ad libitum. Standard management procedures as outlined by Oluyemi and Roberts (2000) were followed.

\section{Data collection and analysis}

Data was collected on growth performance parameters namely final live body weight, weekly live body weight, feed consumption and water intake. Weight gain, feed conversion ratio and water -feed ratios were calculated. Economics of production was also determined while a record of mortality was kept where it occurred following the procedure of Orayaga (2010). The data obtained were subjected to statistical analysis of variance using SPSS (1999), regression was done using MINITAB (2004) and growth pattern was traced using Microsoft Excel (2007).

\section{RESULT AND DISCUSSION}

\section{Chemical composition of mango fruit rejects}

The proximate constituents, energy content and, calcium and phosphorous levels in MFRM were $88.50 \%$ dry matter, 3.24\% crude protein (CP), 3.53\% crude fibre (CF), $1.57 \%$ ether extract (EE), $0.97 \%$ ash, $79.19 \%$ nitrogen free extract (NFE), $3059.55 \mathrm{kcal} / \mathrm{kg} \mathrm{ME}, 0.49 \%$ 
Table 4. Performance of Finisher Broiler Chickens Fed Diets Containing Mango Fruit Reject Meal

\begin{tabular}{|c|c|c|c|c|c|c|}
\hline \multirow{2}{*}{ Parameters } & \multicolumn{6}{|c|}{ Experimental Diets } \\
\hline & 工1 & T2 & $T 3$ & $\mathrm{~T} 4$ & T5 & SEM \\
\hline Initial body weight $(\mathrm{g})$ & 510.78 & 510.94 & 512.19 & 509.38 & 512.35 & - \\
\hline Final body weight $(\mathrm{g})$ & $2142.50^{\mathrm{a}}$ & $1985.0^{\mathrm{ab}}$ & $1987.5^{\mathrm{ab}}$ & $1880.0^{\mathrm{bc}}$ & $1782.5^{c}$ & $54.27^{*}$ \\
\hline Total weight gain $(\mathrm{g})$ & $1631.72^{a}$ & $1474.06^{\mathrm{ab}}$ & $1475.3^{\mathrm{ab}}$ & $1370.63^{\mathrm{DC}}$ & $1270.16^{c}$ & $54.47^{*}$ \\
\hline Daily weight gain(g) & $38.85^{a}$ & $35.10^{\mathrm{ab}}$ & $35.13^{a b}$ & $32.63^{\mathrm{bc}}$ & $30.25^{c}$ & $1.30^{*}$ \\
\hline Daily feed intake $(\mathrm{g})$ & 109.06 & 104.14 & 108.24 & 104.54 & 104.85 & $1.51^{\mathrm{ns}}$ \\
\hline Feed conversion ratio & $2.81^{\mathrm{a}}$ & $2.97^{\mathrm{a}}$ & $2.83^{\mathrm{a}}$ & $3.26^{\mathrm{ab}}$ & $3.47^{\mathrm{D}}$ & $0.15^{*}$ \\
\hline Daily protein intake (g) & 21.81 & 20.83 & 21.65 & 20.91 & 20.97 & $0.30^{\mathrm{ns}}$ \\
\hline Protein conversion efficiency & $1.79^{\mathrm{a}}$ & $1.68^{\mathrm{ab}}$ & $1.61^{\mathrm{D}}$ & $1.56^{\mathrm{DC}}$ & $1.44^{\mathrm{c}}$ & $0.05^{*}$ \\
\hline Daily water intake (ml) & 256.93 & 247.99 & 253.59 & 250.67 & 252.76 & $3.77^{\mathrm{ns}}$ \\
\hline Water-feed ratio $(\mathrm{ml} / \mathrm{g})$ & 2.36 & 2.38 & 2.34 & 2.40 & 2.41 & $0.04^{\mathrm{ns}}$ \\
\hline Mortality (\%) & 0 & 0 & 0 & 0 & 0.025 & - \\
\hline
\end{tabular}

Table 5. The Relationship between Performance Parameter $(Y)$ and Mango fruit Reject Meal Levels (X) That Was Not Significant on Analysis of Variance

\begin{tabular}{llllll}
\hline Parameter & $r$ & $R^{2}$ & Prediction equation & $S_{y x}$ & $P$ \\
\hline Average daily feed intake $(\mathrm{g})$ & -0.55 & 0.3 & $\mathrm{Y}=108-0.16 \mathrm{X}$ & $2.22^{\mathrm{ns}}$ & 0.34 \\
Average daily protein intake $(\mathrm{g})$ & -0.55 & 0.3 & $\mathrm{Y}=21.6-0.032 X$ & $0.44^{\mathrm{ns}}$ & 0.66 \\
Average daily water intake $(\mathrm{ml})$ & -0.26 & 0.07 & $\mathrm{Y}=254-0.113 \mathrm{X}$ & $3.70^{\mathrm{ns}}$ & 0.66 \\
Water/ feed ratio $(\mathrm{ml} / \mathrm{g})$ & 0.66 & 0.44 & $\mathrm{Y}=2.35+0.0024 \mathrm{X}$ & $0.02^{\mathrm{ns}}$ & 0.22 \\
$\mathrm{r}=$ correlation coefficient, $\mathrm{R}^{2}=$ coefficient & of determination, $\mathrm{S}_{\mathrm{yx}}=$ standard error of prediction \\
\hline
\end{tabular}

$\mathrm{P}=$ probability, $\mathrm{ns}=$ not significantly related $(\mathrm{P}<0.05)$

calcium and $0.04 \%$ phosphorus. The Mango fruit reject meal with a protein content of $3.24 \%$ is lower than $4.7 \% \mathrm{CP}$ of mango fruit reported by Palma Castillo and Hurtado (2009) and higher than 1.94 $\pm 0.04-2.36 \pm 0.01 \%$ reported by Imran et al. (2013) for fruit peels only. On a contrary wise, crude protein of mango fruit peel only was reported as $4.6-9.1 \%$ (Rêgo et al., 2010). It was however within $<5 \%$ reported by Kansciet al. (2008). Naveen et al. (2007) reported the proximate of mango fruit pulp alone as $4.2 \% \mathrm{CP}, 6.9 \%$ crude fibre, $2.4 \% \mathrm{EE}$ and $83.3 \%$ NFE.Kansci et al. (2008) reported that mango fruit composition varies greatly. It may therefore be normal to have differences among different reports. It is also likely that the factors making the mango fruits to be rejected by humans such as bruises, infections, premature ripping and or prematured fallen from the tree etc contribute in reducing the protein content as compared to some reports above which were not necessarily of rejected mango fruits but rather byproducts. It could also be due to varietal differences. Ether extract of $1.57 \%$, fibre $3.53 \%$ and ash $0.97 \%$ were all below the reported values of $5.3 \%, 14.6 \%$ and $7.7 \%$, respectively (Palma Castillo and Hurtado, 2009). Factors suggested to be responsible for variation of the protein level in this research to other reports may apply to the other proximate constituents. Nitrogen free extract of $79.19 \%$ is high compared to $67.7 \%$ reported by (Palma Castillo and Hurtado, 2009). The gross energy value of $3019.96 \mathrm{kcal} / \mathrm{kg}$ is less than $17.9 \mathrm{MJ} / \mathrm{kg}(4182.24 \mathrm{kcal} / \mathrm{kg})$ reported byPalma Castillo and Hurtado (2009). Reasons suggested for lower value of mango fruit reject proximate constituents hold for energy as well. While, calcium level of $0.49 \%$ in MFRM is higher than $2.3 \mathrm{~g} / \mathrm{kg}$ reported by Palma Castillo and Hurtado (2009), phosphorous level of $0.04 \%$ is less than $1 \mathrm{~g} / \mathrm{kg}(0.1 \%)$ of their report.

\section{Growth performance}

The growth performance of the finisher broiler chickens is presented in Table 4 and the relationship between level of MFRM and non-significant different $(P>0.05)$ parameters is presented in Table 5 . The final live body weight, total weight gain and daily weight gain of the chickens had a similar pattern of being significantly depressed $(P<0.05)$ at T4 and T5. The birds in T1, T2 and T3 were not significantly different $(P>0.05)$ in all the parameters. Protein conversion efficiency which varied with a high degree of overlaps such that the pairs T1 and T2, T2 and T3, T3 and T4, T4 and T5 were comparable was generally significantly depressed $(P<0.05)$ as the level of MFRM increased. Average daily feed intake $(104.14 \mathrm{~g}-109.06 \mathrm{~g})$ was not significantly different $(P>0.05)$ among treatment groups. The depression in weight might be as a result of the relatively low protein and energy of the diets containing mango fruit rejects meal. These nutrients reduced as the level of MFRM increased in the diets (Table 2). The mango fruit reject 


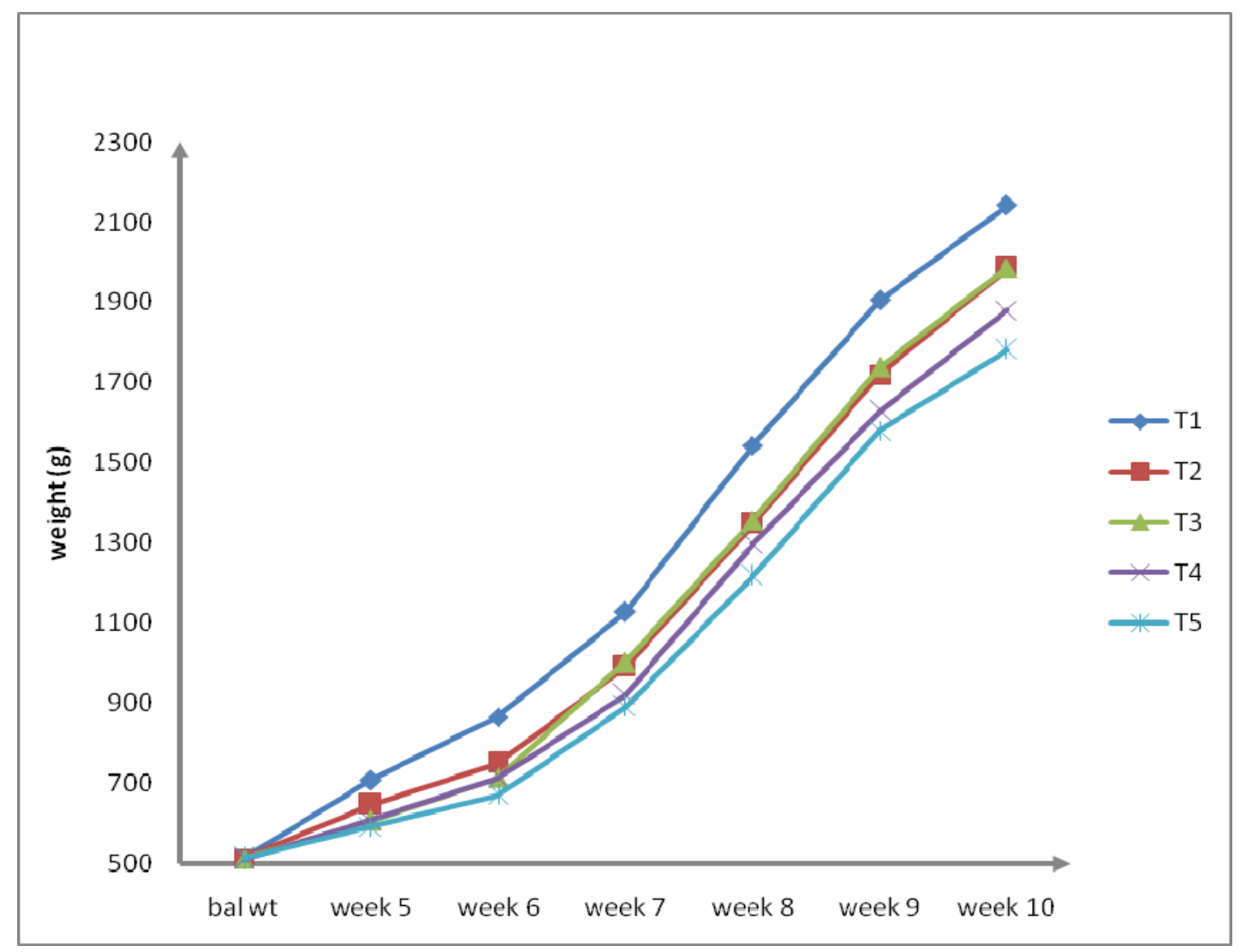

Figure 1. Growth Pattern of Broiler chickens Fed Diets Containing Mango Fruit Reject Meal

used in this experiment had low protein content (3.24\%), compared to maize with 9\% CP (Aduku, 2004). Mango pulp (Palma Castillo and Hurtado, 2009) and peel (Rêgo et al., 2010) are reported to be low in crude protein-2.7 to $6 \%$ and 4.7 to $9 \%$, respectively. As a result, inclusion of MFRM which contains peel and pulp lowered the protein content of the diet thereby making it to be relatively low in crude protein and as such affected growth performance. Though the metabolizable energy of mango fruit reject $(3059.55 \mathrm{kcal} / \mathrm{kg})$ as determined was also lower than that of maize, the major source of energy in the diets, with a ME of $3432 \mathrm{kcal} / \mathrm{kg}$ (Aduku, 2004), it is not likely to be the reason for the depressed performance of the broiler chickens since the energy requirement was met by all the diets.Mango peels are known to contain tannins (Kim et al., 2007) which have been reported to reduce feed consumption by poultry (Oluremi et al., 2007). Feed utilization by birds is affected by tannin levels in the diet and Marquardt et al. (1977) reported that $1.7 \%, 0.5 \%$ and $0 \%$ tannins in chick diets resulted in corresponding daily weight gains of 4,13 and $24 \mathrm{~g}$, respectively. This might be responsible for the lowered protein conversion efficiency and consequent depressed weight gain. The particle size of the diets may also have negative effect on weight gain. Mango fruit reject meal could only be milled to powder and as its inclusion rate increased, the particle size of the diets containing MFRM observably and progressively became smaller than the control. This may thus be one of the reasons for depressed weights observed on birds fed diet containing $15 \%$ and $20 \%$ MFRM. Both particle size and shape affect broiler chicken performance (Axe, 1995). Amerahet al. (2007) reported that the optimum particle size for poultry is $600 \mu \mathrm{m}$ to $900 \mu \mathrm{m}$. However, Nir et al. (1990) classified feed particle size into fine (536 - $574 \mu \mathrm{m})$, medium $(671 \mu \mathrm{m}-773 \mu \mathrm{m})$ and coarse $(871$ $\mu \mathrm{m}-905 \mu \mathrm{m})$. Nir et al. (1994b) reported that particle size uniformity was the most important factor that influences feed utilization. They reported significantly better gain and feed efficiency with birds fed diets having low particle geometric standard deviation. They went further to explain that birds do not waste energy searching for larger grains when particle size is uniform. This might be one reason why the treatment groups fed $15 \%$ and $20 \%$ MFRM had depressed weights, since there was variation in particle size; uniformity of particle size reduced as the level of MFRM increased.

Growth occurred at an increasing rate up to week eight (Figure I) suggesting that economics of the diets would best be determined from week five to week eight, since the birds had a better conversion ratio up to the eight week and declined beyond the week. However, feed 
Table 6. Effect of Mango Fruit Reject Meal on the Economics of Producing Finisher Broiler Chickens

\begin{tabular}{|c|c|c|c|c|c|c|}
\hline \multirow[t]{2}{*}{ Parameters } & \multicolumn{6}{|c|}{ Experimental diets } \\
\hline & $\mathrm{T} 1$ & $\mathrm{~T} 2$ & T3 & $\mathrm{T} 4$ & T5 & SEM \\
\hline Finisher feed cost $(\AA / \mathrm{kg})$ & 108.27 & 103.47 & 98.67 & 93.87 & 89.07 & \\
\hline Cost of feed consumed Per chick ( $\mathbb{N}$ ) & $495.94^{a}$ & $452.55^{\mathrm{b}}$ & $448.55^{\mathrm{b}}$ & $412.13^{\mathrm{C}}$ & $392.24^{d}$ & $6.22^{*}$ \\
\hline Cost per kg weight gain $(\mathbb{A})$ & 303.97 & 307.05 & 304.15 & 305.55 & 309.55 & $10.08^{\text {ns }}$ \\
\hline Operational cost per chicken $(\mathbb{N})$ & 104.40 & 104.50 & 104.50 & 104.50 & 104.50 & - \\
\hline Cost per 28 day-old chicken ( & 650.00 & 650.00 & 650.00 & 650.00 & 650.00 & - \\
\hline Total cost of production per chick ( $($ ) & $1062.66^{\mathrm{a}}$ & $1013.1^{\mathrm{b}}$ & $1003.58^{b}$ & $959.80^{c}$ & $928.68^{d}$ & $7.03^{*}$ \\
\hline Percentage cost of consumed feed & $46.66^{\mathrm{a}}$ & $44.67^{\mathrm{D}}$ & $44.69^{\mathrm{D}}$ & $42.93^{c}$ & $42.24^{\mathrm{c}}$ & $0.37^{*}$ \\
\hline Percentage cost of 28-day old chicken & $43.75^{\mathrm{C}}$ & $45.02^{\mathrm{b}}$ & $44.89^{\mathrm{b}}$ & $46.18^{a}$ & $46.50^{\mathrm{a}}$ & $0.30^{*}$ \\
\hline Percentage cost of operational cost & $9.84^{\mathrm{d}}$ & $10.31^{\mathrm{c}}$ & $10.42^{\mathrm{C}}$ & $10.89^{\mathrm{b}}$ & $11.26^{\mathrm{a}}$ & $0.09^{*}$ \\
\hline Revenue per bird (A) & $1499.75^{a}$ & $1389.5^{\mathrm{ab}}$ & $1391.25^{\mathrm{ab}}$ & $1316.00^{\mathrm{bc}}$ & $1247.75^{\mathrm{a}}$ & $37.99^{*}$ \\
\hline Benefit per bird $(\mathbb{N})$ & 437.09 & 376.37 & 387.72 & 356.21 & 319.33 & $33.46^{\text {ns }}$ \\
\hline Cost/benefit ratio & 2.44 & 2.84 & 2.59 & 3.17 & 2.96 & $0.40 \mathrm{~ns}$ \\
\hline
\end{tabular}

SEM $=$ standard error of mean, ${ }^{\text {ns }}=$ no significant difference $(P>0.05),{ }^{*}=$ significant $(P<0.05),{ }^{a, b, c, d}$ means in the same row with different superscripts are significantly different $(P<0.05), T 1=$ Diet containing $0 \%$ MFRM, T2 = Diet containing 5\% MFRM, T3 = Diet containing 10\% MFRM, T4=Diet containing $15 \%$ MFRM, T5 = Diet containing 20\% MFRM

conversion alone was not adequate to determine economics of production, the revenue was also considered and since the weight determines the revenue per bird, weeks nine and ten, when their average weights attracted acceptable revenue were included in the period under which economics of production was evaluated.

The inclusion of MFRM resulted to significant depression of the final live weight from $2142.50 \mathrm{~g}$ to $1782.50 \mathrm{~g}$, and daily weight gain $38.85 \mathrm{~g}$ to $30.25 \mathrm{~g}$. The former was higher than the final live body weight variation of $778.20 \mathrm{~g}$ to $1675.25 \mathrm{~g}$ (Efionget al., 2012) and $1570.10 \mathrm{~g}$ to $1847.94 \mathrm{~g}$ (Rafiuet al., 2013), but lower than $2149.4 \mathrm{~g}$ to 2254.3g (Soomro et al., 2013), when they fed broiler chickens with diets containing 2 to $4 \%$ mango pulp meal. Feed intake was not significantly affected, suggesting that utilization of the diets rather than intake was the reason for the variation. Feed intake of $104.14 \mathrm{~g}$ to $109.06 \mathrm{~g}$ fell within the feed consumption range of broiler finisher chickens (Oluyemi and Roberts, 2000) The situation where feed intake did not differ significantly among the treatment groups may be due to the ability of matured birds to tolerate higher levels of tannins than the chick. Though the intake was not affected, the utilization was affected with protein conversion efficiency being depressed from T3 (10\% MFRM). Average daily protein intake which ranged from $20.81 \mathrm{~g}-21.65 \mathrm{~g}$ was not significantly different, thereby following the pattern of feed consumption. Increase in tannin levels correspondingly reduced protein utilization (Marquardt et al., 1977). Tannin is known to reduce the nutritional value of a diet mainly due to a decrease in availability of protein for use and impairment of digestive enzyme activity (Haslam, 1981). As a result, nitrogen retention and use of the amino acids are reduced due to the reduction in protein digestibility (Elkin et al., 1995).

Tannin also affects carbohydrates digestion and assimilation due to formation of complex compounds, which are difficult to digest (Mahamood and Smithard, 1993). Vitamins and minerals are also affected by the presence of tannin in the diet (Chang and Fuller,1993). This might be the reason for the significantly depressed performance as clearly shown by the significantly poorer FCR of 3.26 and 3.47 in case of the treatment groups T4 and T5, respectively. Although, there were significant differences, feed conversion ratio of $2.81-3.47$ was within the acceptable range of 2-5 reported by Oluyemi and Roberts (2000). Daily water intake of $247.99 \mathrm{ml}$ to $256.93 \mathrm{ml}$ was within the normal range (Oluyemi and Roberts, 2000; Aduku, 2004). Though, water 
Orayaga et al. 183

Table 7. The Relationship between Economic Parameter $(\mathrm{Y})$ and Mango Fruit Reject Meal Levels (X) that was not Significant on Analysis of Variance

\begin{tabular}{llllll}
\hline Parameter & $r$ & $R^{2}$ & Prediction equation & $S_{y x}$ & $P$ \\
\hline Cost per kg gain & 0.66 & 0.44 & $Y=304+0.193 X$ & $2.01^{\text {ns }}$ & 0.23 \\
Benefit per bird & -0.94 & 0.88 & $Y=426-5.11 X$ & $17.64^{* *}$ & 0.02 \\
Cost -benefit ratio & 0.75 & 0.56 & $Y=2.53+0.0274 X$ & $0.22^{\text {ns }}$ & 0.15 \\
$r=$ correlation coefficient, $R^{2}=$ coefficient of determination, $S_{y x}=$ standard error of prediction \\
\hline
\end{tabular}

$P=$ probability, ${ }^{* *}=$ highly significantly related $(p<0.01), n s=$ not significantly related $(P<0.05)$

consumption is reported to be a function of dry matter intake (Oluyemi and Roberts, 2000), environmental temperature and relative humidity are other factors that influence water intake. Orayaga (2010), regressing and correlating feed intake against water consumption, found no significant relationship and concluded that high temperature and not dry matter intake was responsible for the greater percentage of the water consumed. Waterfeed ratio of 2.34 to $2.41 \mathrm{ml} / \mathrm{g}$ was within the report of 2 to 3 times dry matter intake (Aduku, 2004; Orayaga, 2010).

The quantitative relationships between levels of MFRM inclusion and performance parameters that were not significantly different on analysis of variance showed that none of the parameters was significantly related. This confirms the result of the analysis of variance based on the completely randomized design and there cannot be prediction of level of inclusion of MFRM on these performance parameters. The growth pattern (Figure 1) shows that weight increased at an increasing rate to week 8 and started to decrease after week 8 . This means that feed utilization by broiler chickens was maximum at or before week eight.

\section{Economics of production}

The economics of MFRM in broiler chicken diet is presented in Table 6 and the relationship between the economic parameter not significant $(P>0.05)$ and the level of MFRM, Table 7.There was no significant difference among the treatments for feed cost per $\mathrm{kg}$ weight gain. This means MFRM supported weight gain less than maize because the cost per $\mathrm{kg}$ maize as an ingredient is far higher than the cost per $\mathrm{kg}$ of MFRM. Thus, if MFRM had supported weight gain as did maize, the cost per kg weight gain of the birds would have been lower as the level of MFRM increased in the diets. However, due to its low cost per $\mathrm{kg}$, it became similar to maize economically. The cost of feed consumed, total cost and feed cost as a percent of total cost per bird, however varied significantly $(P<0.05)$. Benefits were however, not significantly different $(P>0.05)$ because though the cost was reduced, the revenue also reduced consequent upon reduced weight. The benefits were however, significantly correlated $(P<0.05)$ negatively, implying that a higher level will most probably result to larger negative effects that will make significant differences on analysis of variance that is based on completely randomized design. Feed cost as a percentage of total cost varied between 42.24 and $46.66 \%$ and was less than the past report of $56.23 \%$ (Singh et al., 2010). This may be due to the prevailing higher cost of the twenty-eight day-old broiler chicken at the time of this study, which represented $43.75 \%$ to $46.50 \%$ of total cost of production.

\section{CONCLUSION AND RECOMMENDATION}

Mango fruit reject meal at $10 \%$ level in broiler finisher diets has supported growth performance as does the control and, similar in economics of production to the control therefore up to $20 \%$.Mango fruit reject meal can be used as a feed resource in finisher broiler chicken diets. It is however, recommended that the optimum level of MFRM in broiler diets should be determined between $10 \%$ and $15 \%$ levels of inclusion.

\section{REFERENCES}

A.O.A.C. (2000). Official Methods of Analysis.Association of Official Analytical Chemists. $16^{\text {th }}$ Ed. William Tryd Press. Richard Virginia, USA. pp 17-34.

Aduku AO (2004). Animal Nutrition in the Tropics: Feeds and Feeding, Pasture Management, Monogastric and Ruminant Nutrition. Davcon Computers \&Business Bureau, Zaria, Nigeria. Pp 5-143.

Amerah AM, Ravindran V, LentleRG , Thomas DG (2007). Feed Particle Size: Implications on The Digestion And Performance of Poultry.World's Poult. Sci. J. 63: 439-455.

Axe DE(1995).Factors affecting uniformity of a mix. Anim. Feed Sci.andTechnol. 53: 211-220.

Berardini N, Fezer R, Conrad J, BeifussU, Carle R,Schieber A(2005). Screening of mango (Mangiferaindica L.) cultivars for their contents of flavonol and xanthone $C$-glycosides, anthocyanins, and pectin.J Agric Food Chem.53 (5): 1563-70.

Chang MJ,Fuller HI (1993). Dietary tannin from cowpeas and tea transiently alter apparent calcium absorption but not absorption of protein in rats. J. Nutr.124:283-288.

Diarra SS, Usman BA (2008). Growth performance and some blood variables of chickens fed raw or boiled mango kernel meal. Inter. J. poult, Sci. 7(4):315 -318.

Effiong OO, Silvester GD,Udoekong EC (2012). Feeding value of toasted Icaciniamanni (earth ball) meal in broiler chicken diets.Sustainable Animal Production for National food security and Poverty Alliviation. Proc. $37^{\text {th }}$ NSAP Conf. 2012, Makurdi, Benue state. Eds: I.I. Bitto, F.G. Kaankuka and S. Attah. Pp $229-234$.

Elkin RG, Featherston WR, Rogler JC (1995). Condensed tannins are only partially responsible for variations in nutrient digestibilities of sorghum grain cultivars.PoultryScience; 74 (1): 125. 
FAO (2011).Top producers of mangoes, mangosteens and guavas.www.fao.com/mango.

Gohl B (1982). Les Aliments du betailSouslesTropiques. FAO, Divission de production el santeAnimale, Rome Italy.

Haslam E (1981). Vegetable tannins. In: Conn EE. The biochemistry of plants,.Academic Press, New York, 7: 527-544.

Imran M, Butt MS, Anjum FM Sultan JI (2013).Chemical Profiling of Different Mango Peel Varieties. Pak. J. Nutr. 12 (10): 934-942.

Kansci G, Koubala BB, Mbome IL (2008).Biochemical and physiochemical properties of four mango varieties and some quality characteristics of the jams.J. food process.Preserv. 32 (4): $644-$ 655.

Kim Y, Brecht JK, Talcott ST (2007). Antioxidant phytochemical and fruit quality changes in (Mangiferaindica L.) following hot water immersion and controlled atmosphere storage. Food Chem.105:1327-34.

Mahmood S,Smithard RA (1993). Comparasion of effects of body weight and feed intake on digestion in broiler cockerels with effects of tannins.British J. Nutr.70:701-709.

Marquardt RR, Ward AT, Campbell LD,Cansfield PE (1977). Purification, identification and characterization of a growth inhibitor in faba beans (Viciafaba L. var. minor). J. Nutr. 107:1313 - 1324.

Microsoft Exel (2007). Statistical analysis. Microsoft inc., U.S.A.

MINITAB (2004).Statistical analysis.MINITAB Student Version 14 for Windows. $\quad 1^{\text {st }}$ ed., Duxbury press, Belmont, NY.

Naveen Z, Prasad JR, Rao ZP (2007). Chemical composition and invitro dry matter digestibility of some fruit wastes. Tamilnadu J. Vet. Anim. Sci. 3(1): 1 - 3 .

Nir I, Melcion JP,Picard M(1990). Effect of particle size of sorghum grains on feed intake and performance of young broilers. Poult. Sci.69: 2177-2184.

NIR I, Shefet G. AARONI Y(1994b).Effect of particle size on performance. 1. Corn. Poult. Sci.73: 45-49.

Odunsi AA (2005). Response of laying hens and growing broilers to the dietary inclusion of mango seed kernel meal.Trop. Anim. Health Prod. 37(2): $139-150$.

Oluremi OIA,Musa SA (2004). The effect of mango seed kernel meal on the performance of growing rabbits. J. Appl. Anim. Res. 25:61-63.

Oluremi OIA, Ngi J, Andrew IA (2007). Phyto-nutrients in citrus fruit peel meal and nutritional implication for livestock production. Livestock Research for Rural Development. vol.19, article89.http: www. Cpav.org.co/irrd/19/7olur19089.hmt.

Oluyemi JA Roberts FA (2000). Nutrient requirement of fowl. In: Poultry production in warm wet climates $\left(3^{\text {rd }} \mathrm{Ed}\right)$. MacMillan Press Lond.Pp.1-140.

Orayaga KT (2010). Effect of duration of water soaking of sweet orange (Citrus sinensis) fruitpeel on its nutritional composition and maize replacement value in broiler diets. M.ScThesis Department of Animal Nutrition, College of Animal Science, University of Agriculture, Makurdi. 140p.

Orayaga KT, Anugwa FOI (2014). The proximate composition of boerhaviadiffusadried leaves and its effect on the growth performance of weaned rabbits. Proc. 39th Conf., Nig. Soc. for Anim. Prod. 16 - 19 March, 2014. Babcock Univ. Ilishan-Remo, Ogun State, Nigeria. Eds. A.R. Abdullah, G.O.Tayo, A.O. Akubanjoand O.A. Akinsoyinu. pp 297-300.

Orayaga KT, Oluremi OIA, Kaankuka FG (2012). Effect of water soaking of sweet orange (Citrus sinensis) fruit peel on its fibre fractions and nutrient digestibility of broiler starter chicks. Proc. $37^{\text {th }}$ Nig. Soc. Anim. Prod.Conf. 2012, Makurdi, Benue state. Ed.: I.I. Bitto, F.G. Kaankuka and S. Attah.Pp $361-365$.

Oyadesi OS, Olusola OO, Olaniyan OO, Adebiyi OA (2012). Performance and carcass traits of broilers fed 'wood ash digested' maize cobs based diets fortified with grandizyme Proc. $37^{\text {th }}$ Nig. Soc. Anim. Prod. Conf. 2012, Makurdi, Benue state.Ed.: I.I. Bitto, F.G. Kaankuka and S. Attah. Pp267 - 270.
Palma Castillo OR, Hurtado EA (2009). Productive behaviour of rabbit during the fattening growth period, fed with mango as partial substitution of the commercial balanced food. RevistaCientificaUdo Agricola 9(4): 968 - 971.

Pauzenga U (1985). Feeding parent stock. J. Zoo Tech. Int:22-24.

Porter $L$ (2011). Nutritional data for dried mango. Official partner of the livingstrongfoundation.www.livingstrong.com/article.

Rafiu TA, Aderinola OA, Akinwumi AO, Alabi TA, Shittu MD (2013). Performance and blood chemistry of broiler chicken fed moringaolivera leaf meal. Proc. $18^{\text {th }}$ Ann. Conf. Anim. Sci. Assoc. Nig. (ASAN), Abuja. Ads: Akpaet al.pp $294-297$.

Rêgo MMT, Neiva JNM, Rêgo AC, Cândido MJD, Alves AA Lôbo RNB (2010). Intake, nutrients digestibility and nitrogen balance of elephant grass silages with mango by-product addition. Rev. Bras. Zootec. 39 (1): 74-80.

Roa DS, Ravi A, Yedukondalu R (2003). Inclusion of dried mango peels in finisher rations of pigs on their performance. Indian J. Anim. Nutr. 20(1): $120-123$.

Singh VP, Sharma VK, Sidhu MS, Kingra HS(2010). Broiler Production in Punjab - An Economic Analysis. Agricultural Economics Research Review 23: 315-324.

Soomro H, Rind MI, Sanjrani SN, Magsi AS, Barham GS, Pirzada SA, Sahito HA (2013). Effect of partialmango pulp mixing in ration on behavior and production of broiler. Inter. J. plant and Anim. Sci. 1(2):30-36.

SPSS (1999).Statistical package for social sciences.Procedures and facilities for release. 6.0 Users' Mannual. McGraw-Hill Book Co.NY.

Sruamsiri S, Silman P (2009). Nutritive value and nutrient digestibility of ensiled mango by-products. Maejo Inter. J. Sci. Technol. 3(03): 371 -378 .

TAC.(2011). Makurdi Weather Elements Records.,Makurdi Metereo logical Station Nigerian Air Force, Tactical Air Command, Makurdi, Nigeria.

USDA.(2010). National Nutrient Database for Standard Reference.SR23, Fruit Reports-09, Mango, raw .pp 449.

Valdez LM, Ronduen BO,Estacio EC (2012).Processing and Utilization of Rejects and Non-Marketable Carabao Mango Fruits".DA-RFU IILIARC, Bacnotan, llocos Norte.

Vieira PAF, De Queiroz JH, Albino LFT, De Moraes GHK, Barboja AD, Muller ES, Viana MTD (2008). Effect of inclusion of mango residues on performance of broiler chickens from 1 to 42 days. Rev. Bras. Zootec. 37 (12): $2175-2178$.

Wikipedia.(2010). Mango varieties.www.fresh plaza.it/images 